\title{
Peningkatan Kemampuan Menulis untuk Menentukan Topik dalam Paragraf Melalui Pendekatan Contextual Teaching and Learning
}

\author{
Margono $^{1}$, Ratu Wardarita ${ }^{2^{*}}$, Dessy Wardiah ${ }^{2}$ \\ ${ }^{1}$ SMP Negeri Bayung Lencir Kabupaten Muba \\ 2Program Pasca Sarjana Universitas PGRI Palembang \\ Jl. Jendral A Yani No 9/10 Ulu Kota Palembang \\ *Email: ratuwardarita@yahoo.com
}

Naskah diterima 10 Agustus 2021, Revisi 15 September 2021, Terbit 29 Oktober 2021

\begin{abstract}
DOI: doi.org/10.21107/pamator.v14i2.11484
Abstract

This study aims to improve writing skills to determine topics in paragraphs through a contextual teaching and learning approach to class VIII students at State Junior High School 8 Bayung Lencir, Muba. The method used is a class room action research method with data in the form of tests classified as quantitative data and data in the form of observations classified as qualitative data. Based on the results of data analysis that has been carried out on class VIII students of State Junior High School 8 Bayung Lencir, Muba from cycle I to cycle III there was a positive increase in each cycle of writing ability to determine topics in paragraphs through a contextual teaching and learning approach. Thus, there is an increase in the results of the writing ability test to determine the topic in the paragraph through a contextual teaching and learning approach
\end{abstract}

Key words: writing ability, topic in paragraph, contextual teaching and learning approach

\section{PENDAHULUAN}

Fungsi utama bahasa adalah sebagai alat komunikasi. Oleh karena itu, pembelajaran bahasa dan sastra Indonesia diarahkan agar siswa terampil berkomunikasi, baik lisan maupun tulisan. Pembelajaran Bahasa dan Sastra Indonesia haruslah diarahkan pada hakikat bahasa sebagai alat komunikasi. Sebagaimana diketahui bahwa sekarang ini pembelajaran bahasa berubah, dari penekanan pada pembelajaran aspek bentuk ke pembelajaran yang menekankan pada aspek fungsi. Umumnya informasi yang diperoleh dari bacaan dapat berpengaruh kepada peningkatan pengetahuan dan keterampilan.

Menulis sebagai salah satu kemampuan berbahasa, membutuhkan keahlian dari seseorang dalam menggunakan bentuk bahasa tulis untuk maksud komunikasi. Oleh karena itu, kemampuan menulis harus melibatkan berbagai keterampilan, yaitu: (1) mengekspresikan ide atau gagasan; (2) mengorganisasikan ide atau gagasan tersebut; (3) menerapkan gramatikal dan pola-pola sintaksis dan (4) memilih struktur dan kosakata.

Pembelajaran bahasa Indonesia yang menjadi salah satu tujuan pembelajaran siswa diharapkan menguasai keterampilan dalam berbahasa. Menurut Tarigan (2008), menjelaskan bahwa keterampilan berbahasa mempunyai empat komponen, yaitu: (1) keterampilan menyimak (listening skills), (2) keterampilan berbicara (speaking skills), (3) keterampilan membaca (reading skills), dan (4) keterampilan menulis (writing skills). Keempat aspek keterampilan tersebut sama pentingnya serta di dalam praktiknya saling mendukung satu sama lain. Keterampilan menulis selalu ada dalam setiap tema pembelajaran dan berhubungan dengan komponen pembelajaran lain. Hubungan tersebut yaitu hubungan antara kemampuan menulis dalam menentukan ide pokok paragraf.

Salah satu bentuk kemampuan menulis adalah menentukan topik dalam paragraf. Djajadisastra (2015) mengemukakan paragraf ialah kesatuan pikiran yang dituangkan dalam beberapa kalimat sebagai unsur dari suatu karangan atau tulisan, yang dimulai dengan baris baru. Setiap paragraf memiliki satu kalimat topik atau ide pokok. Kosasih (2014) menyatakan bahwa paragraf memiliki beberapa fungsi, yaitu: (1) sebagai batas ide pokok yang satu dengan yang lain; (2) sebagai pembuka, penghubung, dan 
penutup suatu wacana; (3) menjalin pertalian kalimat-kalimat untuk mengungkapkan sebuah gagasan; dan (4) tempat pengarang menuangkan ide pokok. Selain pendekatan konvensional dalam proses pembelajaran di sekolah, pendekatan kontekstual merupakan pendekatan lain yang diberikan dalam proses pembelajaran. Pendekatan kontekstual adalah pengajaran yang memungkinkan siswa memperkuat, memperluas, dan menerapkan pengetahuan dan keterampilan akademisnya dalam berbagai latar sekolah dan di luar sekolah untuk memecahkan seluruh persoalan yang ada dalam dunia nyata.

Pendekatan kontekstual merupakan suatu proses pembelajaran holistik yang bertujuan untuk membelajarkan peserta didik dalam memahami bahan ajar secara bermakna (meaningfull) yang dikaitkan dengan konteks kehidupan nyata, baik berkaitan dengan lingkungan pribadi, agama, sosial, ekonomi, maupun kultural. Sehingga peserta didik memperoleh ilmu pengetahuan dan keterampilan yang dapat diaplikasikan dan ditransfer dari satu konteks permasalahan yang satu ke permasalahan yang lain.

Secara garis besar langkah-langkah pendekatan CTL dalam kelas sebagai berikut: (1) kembangkan pemikiran bahwa anak akan belajar lebih bermakna dengan cara bekerja sendiri, menemukan sendiri, dan mengkontruksi sendiri pengetahuan dan keterampilan barunya;(2) laksanakan sejauh mungkin kegiatan inkuiri untuk semua topik. (3) kembangkan sifat ingin tahu siswa bertanya; (4) ciptakan masyarakat belajar (belajar dalam kelompok-kelompok); (5) hadirkan model sebagai pembelajaran; (6) lakukan refleksi di akhir pertemuan; (7) lakukan penilaian yang sebenarnya dengan berbagai cara. (Trianto, 2015).

Berdasarkan uraian di atas, peneliti merasa perlu untuk melakukan penelitian yang berkaitan menentukan topik dalam paragraf dengan menerapkan pendekatan pembelajaran yang inovatif. Kata inovatif, dimaknai sebagai beberapa gagasan dan teknik yang baru. Pembelajaran inovatif adalah pembelajaran yang dikemas guru atas dorongan gagasan baru untuk melakukan perubahan ke arah yang lebih baik lagi dengan mengacu kepada langkahlangkah pembelajaran dengan metode baru, sehingga memperoleh kemajuan hasil belajar (Halim, 2014).

Menurut Anisa (2009), beberapa kelebihan dalam pembelajaran $C T L$, yaitu: (1) pembelajaran lebih bermakna, artinya siswa melakukan sendiri kegiatan yang berhubungan dengan materi yang ada sehingga siswa dapat memahaminya sendiri; (2) pembelajaran lebih produktif dan mampu menumbuhkan penguatan konsep kepada siswa karena pembelajaran CTL menuntut siswa menemukan sendiri bukan menghafalkan; (3) menumbuhkan keberanian siswa untuk mengemukakan pendapat tentang materi yang dipelajari; (4) menumbuhkan rasa ingin tahu tentang materi yang dipelajari dengan bertanya kepada guru; (5) menumbuhkan kemampuan dalam bekerjasama dengan teman yang lain untuk memecahkan masalah yang ada; 6) siswa dapat membuat kesimpulan sendiri dari kegiatan pembelajaran.

SMPN 8 Bayung Lencir merupakan salah satu lembaga pendidikan formal. Bahasa Indonesia adalah salah satu mata pelajaran penting yang dipelajari siswa SMPN 8 Bayung Lencir karena mata pelajaran ini diujikan secara nasional untuk menentukan lulus tidaknya seorang siswa. Beberapa hal yang mendukung tercapainya hasil belajar yang tinggi antara lain berasal dari input siswa yang berupa nilai evaluasi murni (NEM), selain itu media pembelajaran yang digunakan seperti buku literatur, papan tulis, meja belajar dan sarana prasarana pembelajaran lain harus dilengkapi.

Keberhasilan siswa dapat diketahui dari kemampuan siswa di dalam penguasaan materi pelajaran yang dipelajarinya. Hal ini dapat dilihat dari nilai yang diperoleh siswa dalam mata pelajaran tersebut. Dalam pelaksanaan pengajaran di SMPN 8 Bayung Lencir, pencapaian hasil belajar siswa dapat dikatakan belum mencapai hasil secara maksimal. Hal ini dapat dilihat dari pencapaian nilai Bahasa Indonesia pada semester ganjil tahun pelajaran 2018/2019 di kelas VIII masih rendah, dimana masih banyak siswa yang mendapat nilai di bawah Kriteria Ketuntasan Minimal (KKM) yaitu sebesar 70,00. Adapun data dari pencapaian nilai Bahasa Indonesia, khususnya siswa di kelas $\mathrm{VIII}_{2}$ SMPN 8 Bayung Lencir dari 30 orang siswa, yang tuntas dalam proses pembelajaran Bahasa Indonesia sebanyak 
18 orang atau $60 \%$, sedangkan 12 orang siswa atau $40 \%$ belum tuntas. Selain itu, dalam kegiatan belajar-mengajar siswa kurang aktif bertanya dan menjawab pertanyaaan yang diajukan oleh guru, sehingga ada persoalan mengenai keaktifan siswa dalam proses pembelajaran kurang optimal. Apalagi proses pembelajaran saat ini baru memasuki masa new normal, dimana peserta didik dalam mengikuti proses pembelajaran dibagi menjadi dua kelompok, namun proses pembelajaran tatap muka masih dapat dilaksanakan.

\section{METODOLOGI}

Subjek penelitian ini adalah siswa kelas kelas VIII SMP Negeri 8 Bayung Lencir. Metode penelitian yang digunakan dalam penelitian ini adalah penelitian tindakan kelas (PTK). Dengan demikian, penelitian ini sifatnya berbasis kelas, karena dilakukan dengan melibatkan komponen yang terdapat di dalam proses belajar mengajar di dalam kelas, materi kelas dan metode pembelajaran. Penelitian ini dilakukan dengan mengelola dan mengamati sebuah kelas saat kegiatan belajar mengajar berlangsung.

Teknik pengumpulan data tentang upaya meningkatkan kemampuan menulis untuk menentukan topik dalam paragraf siswa siswa kelas VIII SMP Negeri 8 Bayung Lencir melalui pendekatan Contextual Teaching and Learning, meliputi observasi dan tes. Observasi difokuskan pada kemampuan siswa serta memberikan rangsangan keaktifan siswa dalam proses pembelajaran yang sedang berlangsung. Tes dalam penelitian ini, peneliti memberikan instrumen berupa media cetak maupun lainnya melalui pendekatan yang telah ditentukan yang berkaitan dengan kemampuan menulis siswa untuk menentukan topik dalam paragraf. Hasil tes kemampuan menulis untuk menentukan topik dalam paragraf siswa kelas VIII SMP Negeri 8 Bayung Lencir merupakan tolok ukurnya.

\section{HASIL PEMBAHASAN}

Berdasarkan perbandingan aktivitas belajar siswa pada saat proses pembelajaran menulis untuk menentukan topik dalam paragraf melalui pendekatan Contextual Teaching and Learning pada siswa kelas VIII
SMP Negeri 8 Bayung Lencir, diketahui aktivitas belajar siswa mengalami peningkatan yang cukup positif. Hal ini terlihat dari tabel tersebut, pada siklus 1 siswa yang terlibat aktif sebanyak 6 orang siswa atau $24 \%$, kemudian meningkat pada siklus 2 yaitu sebanyak 15 orang siswa atau $60 \%$, dan mengalami peningkatan kembali pada siklus 3 , yaitu sebanyak 23 orang siswa atau $92 \%$.

Tabel 1. Perbandingan Aktivitas Belajar Siswa pada Setiap Siklus

\begin{tabular}{|r|c|r|r|r|r|r|r|}
\hline \multirow{2}{*}{ No } & Keterlibatan & \multicolumn{2}{|c|}{ Siklus 1 } & \multicolumn{2}{|c|}{ Siklus 2 } & \multicolumn{2}{c|}{ Siklus 3 } \\
\cline { 3 - 8 } & $\begin{array}{c}\text { Siswa dalam } \\
\text { Pembelajaran }\end{array}$ & $\begin{array}{c}\text { Jumlah } \\
\text { Siswa }\end{array}$ & $\%$ & $\begin{array}{c}\text { Jumlah } \\
\text { Siswa }\end{array}$ & $\%$ & $\begin{array}{c}\text { Jumlah } \\
\text { Siswa }\end{array}$ & $\%$ \\
\hline 1 & Terlibat Aktif & 6 & 24 & 15 & 60 & 23 & 92 \\
\hline 2 & Terlibat Pasif & 9 & 36 & 7 & 28 & 2 & 8 \\
\hline 3 & Tidak Terlibat & 10 & 40 & 3 & 12 & 0 & 0 \\
\hline & Jumlah & 25 & 100 & 25 & 100 & 25 & 100 \\
\hline
\end{tabular}

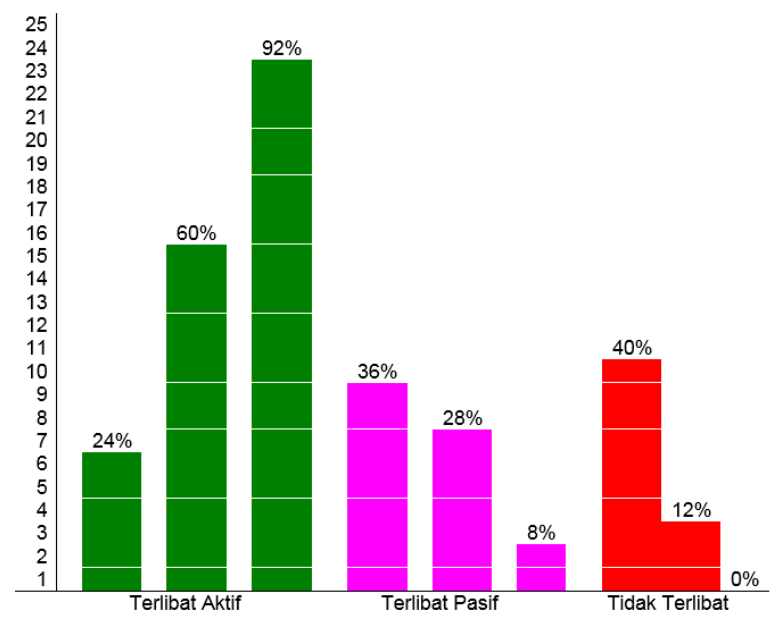

Gambar 1. Perbandingan Keaktifan Belajar Siswa pada Setiap Siklus

Berdasarkan perbandingan aktivitas belajar siswa pada saat proses pembelajaran kemampuan menulis untuk menentukan topik dalam paragraf melalui pendekatan Contextual Teaching and Learning pada siswa kelas VIII SMP Negeri 8 Bayung Lencir pada Tabel 1 di atas, diketahui aktivitas belajar siswa mengalami peningkatan yang cukup positif. Hal ini terlihat dari tabel tersebut, pada siklus 1 siswa yang terlibat aktif sebanyak 6 orang siswa atau 24\%, kemudian meningkat pada siklus 2 yaitu sebanyak 15 orang siswa atau $60 \%$, dan mengalami peningkatan kembali pada siklus 3 , yaitu sebanyak 23 siswa atau $92 \%$. Perbandingan aktivitas belajar siswa pada siklus 1, siklus 2, dan siklus 3 dapat dijelaskan seperti pada Gambar 1. Berdasarkan perbandingan analisis data tes menulis untuk menentukan topik dalam paragraf melalui pendekatan Contextual 
Teaching and Learning pada siswa kelas VIII SMP Negeri 8 Bayung Lencir dari setiap siklus, diketahui bahwa analisis data tes menulis untuk menentukan topik dalam paragraf pada siswa kelas VIII SMP Negeri 8 Bayung Lencir pada siklus 1 diperoleh nilai sejumlah 1573,33 dengan rata-rata sebesar 62,93. Siswa yang mencapai $\mathrm{KKM} \geq 70$ sebanyak 6 orang siswa atau rata-rata persentase pencapaian ketuntasan sebesar $24 \%$.

Setelah dilakukan refleksi untuk dilakukan tindakan berikutnya, yaitu pada siklus 2 , hasil pemerolehan nilai siswa mengalami peningkatan yang cukup positif, yaitu sebesar 1724,67 atau rata-rata pencapaian hasil belajar siswa sebesar 68,99. Siswa yang mencapai $K K M \geq 70$ sebanyak 16 orang siswa atau rata-rata persentase pencapaian ketuntasan sebesar 64\%. Hal ini menunjukkan terdapat peningkatan yang cukup positif, walaupun hasil belajar siswa yang diharapkan belum mencapai hasil yang ditetapkan.

Perbaikan demi perbaikan dilakukan untuk mencapai hasil yang diharapkan, terlebih dahulu penulis melakukan refleksi dan melihat faktor-faktor yang menjadi penghambat tidak tercapainya nilai KKM yang ditetapkan dalam menulis. Setelah faktor-faktor diperoleh, penulis mengkaji ulang agar tindakan berikutnya pada proses pembelajaran tidak terulang lagi. Peneliti memperdalam pemahaman melalui model pembelajaran langsung yang dikaitkan dunia nyata dalam kehidupan sehari-hari siswa. Siswa diajak bersenda gurau dalam proses pembelajaran tetapi tetap fokus pada materi menulis untuk menentukan topik dalam paragraf melalui pendekatan Contextual Teaching and Learning pada siswa kelas VIII SMP Negeri 8 Bayung Lencir.

Terbukti dari hasil kolaborasi melalui pendekatan konvensional dan pendekatan Contextual Teaching and Learning, siswa mampu menulis untuk menentukan topik dalam paragraf. Hasil yang diperoleh pada siklus 3 diketahui pemerolehan nilai siswa sebesar 2031,97 atau rata-rata pencapaian hasil belajar siswa sebesar 81,28. Siswa yang mencapai $\mathrm{KKM} \geq 70$ sebanyak 23 orang siswa atau rata-rata persentase pencapaian ketuntasan sebesar 92\%. Hal ini menunjukkan terdapat peningkatan yang cukup positif dan baik sekali. Dengan demikian, hasil yang diperoleh dalam menulis untuk menentukan topik dalam paragraf telah mencapai nilai yang ditetapkan, maka peneliti tidak melanjutkan pada tindakan berikutnya dikarenakan nilai yang diperoleh dalam menulis untuk menentukan topik dalam paragraf sudah mencapai nilai $\mathrm{KKM} \geq 70$, dan pencapaian nilai secara klasikal sebesar $85 \%$ dapat dikatakan sudah tercapai, dikarenakan ketuntasan belajar siswa sebesar $92 \%$. Analisis perbandingan data tes kemampuan menulis untuk menentukan topik dalam paragraf dapat digambarkan seperti terlihat pada Gambar 2.

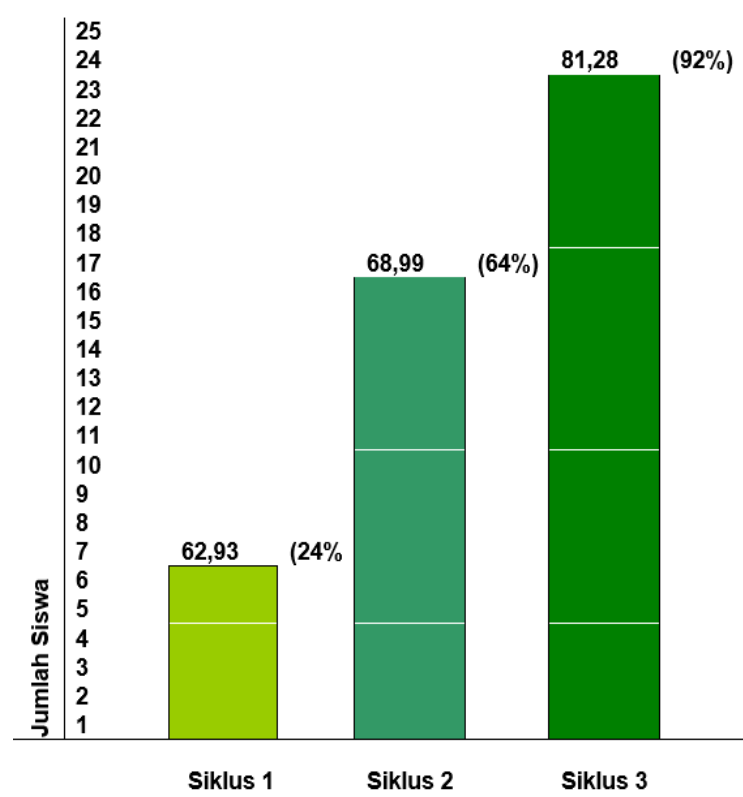

Gambar 2. Grafik Ketuntasan Belajar Siswa pada Setiap Siklus

Siswa yang terlibat pasif pada saat proses pembelajaran menulis untuk menentukan topik dalam paragraf melalui pendekatan Contextual Teaching and Learning pada siswa kelas VIII SMP Negeri 8 Bayung Lencir, terlihat pada perbandingan tersebut mengalami peningkatan yang baik. Hal ini terlihat pada tabel tersebut pada siklus 1 siswa yang pasit sebanyak 9 orang siswa atau $36 \%$, kemudian berkurang pada siklus 2 , yaitu sebanyak 7 orang siswa atau $28 \%$, kemudian berkurang kembali pada siklus 3 , yaitu sebanyak 2 orang siswa atau $8 \%$. Hal ini membuktikan bahwa siswa mulai memperhatikan kegiatan proses pembelajaran menulis untuk menentukan topik dalam paragraf lebih baik lagi.

Siswa yang tidak terlibat pada proses pembelajaran menulis kemampuan menulis 
untuk menentukan topik dalam paragraf pada siklus 1 berjumlah sebanyak 10 orang siswa atau $40 \%$. Siswa masih banyak yang tidak memperhatikan, bahkan ada beberapa siswa yang masih terlihat mengobrol dengan temannya, kemudian pada siklus 2 setelah diberikan pengarahan dan diberikan teguran, siswa mulai tampak memperhatikan kegiatan proses pembelajaran tersebut. Hal ini terbukti siswa yang tidak terlibat mulai berkurang, yaitu sebanyak 3 orang siswa atau $12 \%$. Namun, proses pembelajaran yang diberikan kepada siswa sekolah dasar tentu tidak sama dengan siswa sekolah menengah.

\section{KESIMPULAN}

Terdapat peningkatan yang cukup positif dari setiap siklus kemampuan menulis untuk menentukan topik dalam paragraf melalui pendekatan Contextual Teaching and Learning pada siswa kelas VIII SMP Negeri 8 Bayung Lencir. Terdapat peningkatan hasil data tes kemampuan menulis untuk menentukan topik dalam paragraf. Peningkatan keaktifan belajar siswa terlihat pada siklus 1 siswa yang terlibat aktif sebanyak 6 orang siswa atau 24\%, kemudian meningkat pada siklus 2 yaitu sebanyak 15 orang siswa atau $60 \%$, dan mengalami peningkatan kembali pada siklus 3 , yaitu sebanyak 23 orang siswa atau $92 \%$.

Tes kemampuan menulis untuk menentukan topik dalam paragraf pada siklus 1 sebanyak 6 orang siswa atau rata-rata persentase pencapaian ketuntasan sebesar $24 \%$. Kemudian pada siklus 2, hasil perolehan nilai siswa mengalami peningkatan yang cukup positif, yaitu sebanyak 16 orang siswa atau rata-rata persentase pencapaian ketuntasan sebesar $64 \%$. Selanjutnya pada siklus 3 diketahui sebanyak 23 orang siswa atau rata-rata persentase pencapaian ketuntasan sebesar $92 \%$.

\section{DAFTAR PUSTAKA}

Carderonello, A.H., \& Edward, J. (1986). The process of writing. Boston: Hounghton Miffin.

Djajadisastra, J.(2015). Bahasa indonesia, mendengarkan dan membaca. Bandung: PPPG Tertulis.

Halim. (2014). Dasar-dasar keterampilan menulis. Jakarta. Rineka Cipta.

Hanafiah. (2010). Tujuan pembelajaran melalui pendekatan CTL (Contextual Teaching and Learning). Jakarta: Rajawali Pres.

Kosasih. (2014). Kompetensi ketatabahasaan SMP cermat berbahasa Indonesia. Bandung: Yrama Widya.

Nadhirin. (2010). CTL (Contextual Teaching and Learning) menjadikan kegiatan belajar-mengajar mengasyikkan dan bermakna. Jakarta: Raja Graffindo Persada.

Nurgiyantoro, Burhan. (2010). Pengajaran bahasa dan sastra indonesia. Yogyakarta: BPFE.

Semi, M. Atar. (2007). Dasar-dasar keterampilan menulis. Bandung: Angkasa.

Suyatno. (2009). Teknik pembelajaran bahasa dan sastra. Surabaya: SIC.

Tarigan, Henry Guntur. (2008). Menulis sebagai suatu keterampilan berbahasa. Bandung: Angkasa.

Trianto. (2015). Mendesain model pembelajaran inovatif progresif. Jakarta: Kencana. 